Golden Gate University School of Law GGU Law Digital Commons

$5-2003$

\title{
Making Sense Out of Insurance, Condemnation, and Settlement Clauses in Deeds of Trust
}

Roger Bernhardt

Golden Gate University School of Law, rbernhardt@ggu.edu

Follow this and additional works at: http://digitalcommons.law.ggu.edu/pubs

Part of the Property Law and Real Estate Commons

\section{Recommended Citation}

Bernhardt, Roger, "Making Sense Out of Insurance, Condemnation, and Settlement Clauses in Deeds of Trust" (2003). Publications. Paper 332.

http://digitalcommons.law.ggu.edu/pubs/332

This Article is brought to you for free and open access by the Faculty Scholarship at GGU Law Digital Commons. It has been accepted for inclusion in Publications by an authorized administrator of GGU Law Digital Commons. For more information, please contact jfischer@ggu.edu. 
May 2003

Making Sense Out of Insurance, Condemnation, and Settlement Clauses in Deeds of Trust

Roger Bernhardt

\section{Introduction}

I predict that two consequences will flow from the Ninth Circuit's recent decision in Kasdan, Simonds, McIntyre, Epstein \& Martin v World Sav. \& Loan Ass'n (In re Emery) (9th Cir 2003) 317 F3d 1064, reported at $\mathrm{p} 168$, holding that moneys received by trustors in settlement of their damage claims against their contractor need not be turned over to their lender. First, no other court is likely to agree with the logic announced by the court. Second, all lenders will rewrite their deed of trust forms to completely escape that reasoning — and its consequences—anyway. To a large degree, therefore, this commentary may be an exercise in futility, although I will try to redeem it by some broader observations at the end.

(For those of you who have not yet read the case summary, what happened is that a law firm settled with their clients' contractor over construction defects, paid $\$ 335,000$ of the funds received over to the clients, and retained $\$ 200,000$ for their fees. The clients, trustors under a deed of trust, pocketed the money, defaulted on their loan, and filed bankruptcy. The lender got the stay lifted, foreclosed, underbid, and then went after the law firm for converting money that it said belonged to it. The bankruptcy court held for the law firm, the district court held for the lender, and the Ninth Circuit ultimately held for the law firm, on the ground that no funds belonging to the lender had been converted.)

\section{Was Anything Owed?}

The reasoning of the Ninth Circuit in concluding that none of the settlement belonged to the lender is so unusual that it forms the basis of my first opinion that other courts are unlikely to agree. The deed of trust provision covering funds arising from any action against third parties "for injury or damages to the Property ... and which arose or will arise before or after the date of this Security Instrument" clearly included this settlement, and nobody seemed to contend otherwise on that issue. But the fact that the funds were assigned to be applied to "any amount that I may owe to Lender under the Note and this Security Instrument" is what killed the lender. Since other provisions in the document refer to "sums secured," the court declared that the amount owed was "zero," so long as the trustors were not currently in default on their payments. (I must observe with amusement that this same deed of trust, in defining the note, stated: "The note shows that I owe Lender U.S. \$450,000 plus interest" (my italics). I got this and a few other facts from the underlying file rather than from the opinion itself.)

Well, I wish I could state on my loan applications that I do not "owe" anything on all my debts, simply because I happen to not be in default on them at that moment. And when I asked two friends how much they owed on their mortgages, they each replied with the principal balances on their loans, not the overdue arrearages. A case I have in my casebook on dragnet clauses says (Langerman v Puritan Dining Room (1913) 21 CA 637, 642, 132 P 617): 
A debt, whether legally enforceable at the present time or at some future time, constitutes an existing obligation, and when we refer to a debt we at once understand thereby that thus there is resting upon some one an obligation to pay money to another when the time fixed by the parties, or by law, for its payment has ripened.

I take this to mean that money can be owed long before it is payable. To me, the way the court uses the word "owe" is not at all what most of us mean when we use it.

\section{Hedging Against Similar Results}

But kicking around an opinion just because you think the judges got it wrong is not productive activity. (Law professors may delight in doing so, but it too readily seduces students into thinking they can ignore any rule they don't like.) Even though people may continue to speak and write the same way as before, it is not impossible for judges to begin limiting "owed" to "amounts currently due and payable," despite its common contrary usage, as happened here. Careless inclusion of that word in a document could become costly.

As a result of this opinion, the obvious change I would expect this lender to make is to revise its deed of trust provision covering assignment of litigation proceeds to have the money applied to all "sums secured"-the term that is used in the related insurance and governmental taking provisions - and to make sure that the definition of that phrase is broad enough to cover all possibilities. If the lender lost the Emery case because of what its deed of trust said, then saying it differently should let it win the next one.

I would also suggest that attorneys make a computer scan of all of their documents for the word "owed" to see if it appears in any dangerous context. (For instance, if interest is to be charged on all sums owed, do you really want to make the unpaid balance due interest-free?) Too often, one paragraph of a document is revised in response to some recent adverse ruling without due consideration of all the companion paragraphs in the instrument.

\section{Don't Let Consistency Trump Sensitivity}

The above advice does not, however, mean that the three paragraphs in a deed of trust covering insurance, condemnation, and settlement proceeds should be identical in all respects. Based on past cases, there are different lessons to be learned for each, a few of which I will mention here in the remaining space allotted to me.

1. Insurance Proceeds. Property insurance proceeds are products of private contracts, so insurance proceeds paid after a casualty to the trustors' property do not belong to the lender. The lender can reach them only if the deed of trust was properly worded. If the particular risk was not required to be covered-as is true of earthquakes, for example-then a trustor who has independently elected to insure against that risk can keep the proceeds despite the effect on the lender's security. See Ziellov Superior Court (1995) 36 CA4th 321, 42 CR2d 251; Foothill Village Homeowners Ass'n v Bishop (1999) 68 CA4th 1364, 81 CR2d 195. (However, a back door route to these funds may exist if the deed of trust assigns all insurance proceeds to the lender, even for hazards that were not required to be covered. See JEM Enters. $v$ Washington Mut. Bank (2002) 99 CA4th 638, 121 CR2d 458; Martin v World Sav. \& Loan Ass'n (2001) 92 CA4th 803, 112 CR2d 296.)

Emery, of course, advises lenders that such assigned insurance proceeds should not be limited to being applied to what the trustor then owes. On the other hand, in Schoolcraft v Ross (1978) $81 \mathrm{CA} 3 \mathrm{~d} 75,146 \mathrm{CR} 57$, the judges' refusal to allow a lender to claim the proceeds when the 
trustor wanted to use them to rebuild is probably not a result that better drafting can overrule. But the permission granted to lenders by CC $\$ 2924.7$ (b) to reach the funds, regardless of any impairment of security issue, seems to mean that even the amply oversecured lender can take the entire award without needing a special clause to that effect.

2. Condemnation Awards. Because these awards constitute substitute security, a lender has a claim to them even when the deed of trust is entirely silent on that issue. But here the doctrine of impaired security may come into play and limit that claim to only what is necessary to restore the lender's previous loan-to-value ratio. See Milstein v Security Pac. Nat'l Bank (1972) 27 CA3d 482, 103 CR 16; People ex rel Dep't of Transp. v Redwood Baseline (1978) 84 CA3d 662, 149 CR 11. The elimination of the impairment requirement in CC $\$ 2924.7$ applies only to insurance awards, and I cannot really say whether good language will let the lender keep the entire award, even when its loan is quite safe anyway.

3. Litigation Awards and Settlements. This situation got off to a bad start in 1968 when Justice Traynor held that a deed of trust provision covering damages awarded for injury to property did not apply to the money received by the trustors in settlement of their fraud claims against their sellers. American Sav. \& Loan Ass'n v Leeds (1968) 68 C2d 611, 68 CR 453. That probably explains the far broader language used in Emery, as well as why that clause goes on to say that "injury or damages" includes claims for breach of contract, fraud, concealment, and negligent or intentional acts. Without this provision, some of those recoveries might qualify as substitute security, but many would not. And-if impairment of security is a factor-when does the security become impaired upon the discovery of a previously unknown defect?

Finally, all of this still leaves open the very interesting question that the Ninth Circuit left unresolved: To what degree must the borrowers' lawyers take steps to ensure that the security interests of their clients' lender remain protected. When is the last time you thought it wise to tell your homeowner clients that you felt duty bound to notify their bank in order to make sure that their recovery would be taken away from them by the bank as soon as they got it?

Kasdan, Simonds, McIntyre, Epstein \& Martin v World Sav. \& Loan Ass'n (In re Emery) (9th Cir 2003) 317 F3d 1064

In 1993, the Emerys refinanced their home through World Savings (World). As security for the loan, the Emerys executed a deed of trust in favor of World that assigned to World the Emerys' rights in any legal cause of action relating to injury or damage to their home. After refinancing, the Emerys discovered construction defects and litigation ensued. After payment of attorney fees $(\$ 198,686)$ and costs $(\$ 62,250)$, the Emerys' net share of the settlement proceeds totaled $\$ 335,272$. The Emerys' attorney (Kasdan) disbursed this amount to them and their creditors in 1996. Neither the Emerys nor Kasdan notified World of the suit.

The Emerys defaulted on their loan to World and filed for bankruptcy. Although World foreclosed, it did not recoup the full amount of the Emerys' indebtedness. World sued Kasdan for conversion of the settlement proceeds. The bankruptcy court entered summary judgment for Kasdan and the district court reversed.

The Ninth Circuit reversed, holding that Kasdan did not convert the settlement proceeds. Even assuming the provision in the deed of trust for assignment of rights created a property interest capable of being converted, World did not have an immediate possessory interest in the litigation 
proceeds. The deed of trust did not vest World with exclusive rights to the settlement proceeds but only entitled World to demand the amount that the Emerys "owed" to it. At the time Kasdan distributed the settlement proceeds, the Emerys were not in default. Because the amount "owed" to World was therefore zero, Kasdan did not injure World by disbursing settlement funds directly to the Emerys. The court refused to interpret the deed of trust so that the amount "owed" to World included the entire outstanding balance of the underlying loan, regardless of the Emerys' default status, because that would result in an acceleration clause triggered by a recovery by the borrower of damages for injury to the property.

The court also concluded that Kasdan did not convert World's cause of action for construction defects. Even assuming that the chose-in-action was the type of property interest that can be converted, World did not have an exclusive right to litigate that underlying cause of action. The deed of trust merely gave World the right, "at its option," to pursue legal action, but did not divest the Emerys of their right to pursue legal action if World did not exercise that option. The Emerys retained the right to litigate, conditional on World's right to intervene. Although World was deprived of the opportunity to intervene (because the Emerys failed to alert World about the underlying litigation), that might support a breach of contract claim against the Emerys, but did not support World's conversion claim against Kasdan. 